Bioscientia Medicina: Journal of Biomedicine \& Translational Research

Journal Homepage: www.bioscmed.com

\title{
Analysis of Risk Factors with the Degree of Pelvic Organs Prolapse at Dr. Mohammad Hoesin General Hospital Palembang
}

\section{Hadrians Kesuma Putra ${ }^{*}$, Callista Zahra Aidi², M. Zulkarnain ${ }^{2}$}

${ }^{1}$ Department of Obstetry and Gynecology, Faculty of Medicine, Universitas Sriwijaya, Palembang, Indonesia

${ }^{2}$ Undergraduate Student, Study Program of Medical Education, Faculty of Medicine, Universitas Sriwijaya, Palembang, Indonesia

\section{A R T I C L E I N F O}

Keywords:

Pregnancy

Urinary bladder

Parity

Incidence

Chi-square distribution

\section{*Corresponding author:}

Hadrians Kesuma Putra

\section{E-mail address: \\ hadrianskesuma@fk.unsri.ac.id}

All authors have reviewed and approved the final version of the manuscript.

\begin{abstract}
A B S T R A C T
Background. Pelvic organ prolapse (POP) is a condition in which one or more pelvic organs (consisting of the uterus, vaginal cuff, bladder, intestines, and rectum) or more are still in or out of the vagina. Risk factors that influence the incidence of POP consist of obstetric risk factors (number of parity and birth method) and nonobstetric risk factors (age, menopause, BMI, comorbid disease, and hypertension). The purpose of this study was to analyze the risk factors associated with the degree of POP. Methods. This study is an observational study with a cross-sectional approach to 111 patients examined at the Department of Obstetrics and Gynecology, Dr. Mohammad Hoesin general hospital Palembang on January 2017 to December 2019, who was diagnosed with pelvic organ prolapse. Results. The results showed the effect of variables with the degree of POP using the chi-square test, consisting of parity $(p=0.007)$, birth method $(p=<0.001)$, age $(p=0.016)$, menopause $(p=0.001)$, BMI $(p=0.005)$, indicates that there is a significant effect on the degree of POP. Meanwhile, comorbid factors $(p=0.481)$ and hypertension $(p=0.415)$ did not show a significant relationship with the degree of POP. The results of the binary logistic regression analysis of all risk factors, the number of parity $>4$, overweight, and age 40 years, will have a $99.85 \%$ chance of experiencing grade 3 or 4 prolapse. Conclusion. Age is the most dominant risk factor affecting the degree of pelvic organ prolapse, with 19 times the chance of developing POP 3 or 4 degrees.
\end{abstract}

https://doi.org/10.32539/bsm.v5i11.366

\section{Introduction}

Pelvic organ prolapse is a condition in which there is a decrease or protrusion of one pelvic organ (consisting of the uterus, vaginal cuff, urinary bladder, intestine, and rectum) or more with the condition still in or out of the vagina. In recent years, there has been an increase in life expectancy in developing countries; medical personnel is expected to recognize diseases that often occur in elderly patients, especially obstetricians and gynecologists, to deal with pelvic organ prolapse ${ }^{1}$. Based on previous study in 2013, the incidence of pelvic organ prolapse is 3-6\% based on symptoms and $50 \%$ based on vaginal examination. There are 200,000 pelvic organ prolapse surgeries performed annually in developed countries such as the United States, indicating recurrence or reoperation of $30 \% 2$. More than 47 cases of pelvic organ prolapse every year, and in 2005-2010, 260 cases received surgery based on data from Cipto Mangunkusumo Hospital $^{3}$. Risk factors that influence the incidence of POP consist of obstetric risk factors (number of parity,method of delivery) and non-obstetric risk factors (age, menopause, BMI, comorbid factors, and hypertension) ${ }^{4}$.

\section{Methods}

This research is an observational study with a 
cross-sectional approach. The design of this study can determine the relationship between patients who have risk factors for pelvic organ prolapse with a high or low incidence of pelvic organ prolapse. This research was conducted in December 2020 at the Medical Record Installation of Dr. Mohammad Hoesin Palembang. The population and sample in this study were patients diagnosed with pelvic organ prolapse at the Department of Obstetrics and Gynecology, Dr. Mohammad Hoesin Palembang in January 2017 until December 2019, consisted of pelvic organ prolapse patients, namely: cystocele, uterine prolapse, rectocele, and vaginal crest prolapse and met the inclusion and exclusion criteria. Samples were collected using a total sampling method following the rules contained in the medical record installation. According to the required data, the inclusion criteria in this study were patients with complete medical records, while the exclusions were patients with gynecological malignancies, patients with internal or external genitalia. All data were then collected and analyzed univariately, bivariate using chisquare test and multivariate with binary logistic regression. The research variable was the degree of pelvic organ prolapse as an independent variable. Risk factors used as research variables include parity, delivery method, age, menopause, BMI, comorbid factors, and hypertension.

\section{Result}

There was 111 patient who met inclusion criteria. Table 1 shows the distribution of pelvic organ prolapse degree in patients. Most of the patients (48.6\%) were experienced grade 4 pelvic organ prolapse. Based on the number of parity, most patients had parity numbers of more than four $(68.5 \%)$.

Table 1. Characteristic of pelvic organ prolapse patients

\begin{tabular}{|c|c|}
\hline Characteristics & Frequency $(n=111)$ \\
\hline \multicolumn{2}{|l|}{ Age } \\
\hline Less than 40 years & $4(3.6 \%)$ \\
\hline More than 40 years & 107 (96.4\%) \\
\hline \multicolumn{2}{|l|}{ Grading } \\
\hline Grade 2 & $13(11.7 \%)$ \\
\hline Grade 3 & 44 (39.6\%) \\
\hline Grade 4 & $54(48.6 \%)$ \\
\hline \multicolumn{2}{|l|}{ Number of parity } \\
\hline Less or same with 4 & $35(31.5 \%)$ \\
\hline More than 4 & 76 (68.5\%) \\
\hline \multicolumn{2}{|l|}{ Birth methods } \\
\hline Vaginal birth & $109(98.2 \%)$ \\
\hline Caesar section & $2(1.8 \%)$ \\
\hline \multicolumn{2}{|l|}{ Menopause } \\
\hline Yes & 105 (94.6\%) \\
\hline No & $6(5.4 \%)$ \\
\hline \multicolumn{2}{|l|}{ Overweight } \\
\hline Yes & $53(47.7 \%)$ \\
\hline No & $58(52.3 \%)$ \\
\hline
\end{tabular}


Based on the method of delivery, 109 (98.2\%) study subjects delivered vaginally, and by age, only $4(3.6 \%)$ subjects were aged $<40$ years, and $107(96.4 \%)$ subjects were aged $\geq 40$ years. Based on menopause, as many as 105 (94.6\%) study subjects had experienced menopause, and only $6(5.4 \%)$ research subjects had not experienced menopause. A total of 53 (47.7\%) study subjects had a BMI of 25 or overweight, and there were
$58(52.3 \%)$ study subjects who were not overweight or had a BMI <25. Table 2 presents the relationship between the number of births and the degree of pelvic organ prolapse. Using the Chi-Square test, $\mathrm{p}$-value = 0.007 , where $\mathrm{p}$-value $>0.05$, it was concluded that there was a significant relationship between parity and the degree of pelvic organ prolapse.

Table 2. Relationship of number of paritas and POP degree

\begin{tabular}{|c|c|c|c|c|c|}
\hline \multirow{2}{*}{$\begin{array}{c}\text { Number of } \\
\text { paritas }\end{array}$} & \multicolumn{3}{|c|}{ POP degree } & \multirow[t]{2}{*}{ Total } & \multirow[t]{2}{*}{ p-value } \\
\hline & 2 & 3 & 4 & & \\
\hline$\leq 4$ & $9(8.1 \%)$ & $13(11.7 \%)$ & 13 (11.7\%) & 35 (31.5\%) & 0.007 \\
\hline$>4$ & $4(3.6 \%)$ & 31 (27.9\%) & 41 (36.9\%) & 76 (68.5\%) & \\
\hline
\end{tabular}

\section{Discussion}

According to a study by Sze et al., multipara was a risk factor for the occurrence of degrees 2,3 and 4 of pelvic organ prolapse compared with nulliparous women. This can occur due to trauma resulting from repeated childbirth and results in progressive damage to the muscles and nerves of the pelvis, causing the pelvic floor muscles to experience weakness and a decrease in the pelvic organs. Each increase in parity with vaginal delivery increases the incidence of pelvic organ prolapse to a higher degree 5 . Vaginal birth also causes stretching and trauma to the endopelvic fascia (uterosacral ligament, cardinal ligament), lacerations of the perineal body (perineum), and levator ani muscles, as well as mechanical and pudendal nerve damage in women with pelvic organ prolapse. Mechanical trauma results from the fetal head pressure during delivery, forcing and tearing the pelvic floor muscles and fasciab7.

Age influences the degree of pelvic organ prolapse. This fact is supported by previous studies, which state that there is a significant effect between age and pelvic organ prolapse and the resulting weakness of pelvic floor muscles and tissues in older women8. This occurs due to physiological changes, from the ovarian function, which begins to decline due to menopause in women with advanced age. The decrease in the hormone estrogen results in atrophy of the genital tract organs, weakening of the pelvic floor muscles, weakening of the uterosacral and cardinal ligaments, weakening of the endopelvic fascia to stretch, and easy pelvic organ prolapse. ${ }^{9-11}$

Menopause causes a decrease in the hormone estrogen, resulting in tissue weakness due to changes in the synthesis and degradation of extracellular matrix proteins, which this proteins help in tissue stability and keep collagen from being degraded. This can be caused by the reduced production of estrogen caused by menopause, resulting in reduced expression of type I collagen, which has elastic properties and has a significant and robust resistance to tension and increased expression of type III collagen, which has the role of increasing tissue elasticity and stretch, resulting in decreased strength in supporting pelvic floor organs in pelvic organ prolapse patients. ${ }^{12-13}$

\section{Conclusion}

Pelvic organ prolapse has risk factors, namely multipara (more than four births), vaginal birth, age more than 40 years, menopause, and overweight. Age is the dominant risk factor affecting the degree of pelvic organ prolapse. 


\section{References}

1. Sayko SK, Kurniawati EM, Lestari P. Age as the risk factor that affected the increased degree of uterine prolapse. Biomol Health Sci J, 2018, $1: 20$.

2. Pelvic organ prolapse : a guide for women.. International Urogynecological Association, 2013, 24:1783-90.

3. Hardianti, B. Faktor Faktor yang Berhubungan dengan Kejadian Prolapsus Uteri di RSUP Dr Kariadi Semarang. 2015. Semarang: Fakultas Kedokteran Universitas Diponegoro.

4. Kim CM, Jeon MJ, Chung DJ, Kim SK, Kim JW. Risk factors of pelvic organ prolapse. Int $\mathrm{J}$ Gyn Obs, 2007, 98: 248-51.

5. Hwang JY, Kim B, Song SH. Parity: a risk factor for decreased pelvic floor muscle strength and endurance in middle-aged women. Int Urogyn J, 2019, 16: 356-60.

6. Trutnovsky G, Kamisan AI, Martin A, Dietz HP. Delivery mode and pelvic organ prolapse: a retrospective observational study. Int $\mathrm{J}$ Obs Gyn, 2016, 123: 1551-6.

7. Faluvianti IS. Perbedaan fungsi seksual pasien prolapsus uteri antara terapi operatif dan nonoperatif di RSUD Dr. Soetomo Surabaya. Universitas Airlangga, 2016, 1-118.

8. Carlin GL, Bodner K, Kimberger O, Haslinger $\mathrm{P}$, Schneeberger $\mathrm{C}$, et al. The role of transforming growth factor- $\$$ (TGF-ß1) in postmenopausal women with pelvic organ prolapse: An immunohistochemical study. Eur J Obs Gyn Reprod Bio, 2019, 7:1-5.

9. Sakti D. Ekspresi kolagen I dan III ligamentum sakrouterina pada perempuan dengan dan tanpa prolaps organ panggul. Universitas Hasannudin. 2012.

10. Rechberger T, Nowakowski $€$, Rechberger E, Zietek A, Winkler I, et al. Prevalence of common comorbidities among urogynaecological patients. Gin Polska, 2016, 87: 34-6.

11. Wibisono J, Hermawan G. Prolaps Organ Panggul. Medicinus, 2019, 7:27.
12. Isik H, Aynioglu O, Sahbaz A, Selimoglu R, Timur $\mathrm{H}$, et al. Are hypertension and diabetes mellitus risk factors for pelvic organ prolapse? Eur J Obs Gyn Reprod Bio 2016, 197: 59-62.

13. Papavramidis TS, Marinis AD, Pliakos I, Kesisoglou I, Papavramidou N. Abdominal compartment syndrome, intra-abdominal hypertension: Defining, diagnosing, and managing. J Emerg Trauma Shock, 2011, 4:279-91 